\title{
Pertumbuhan Puyuh (Coturnix coturnix japonica L.) Setelah Pemeliharaan dengan Cahaya Monokromatik
}

\section{The Growth of Quail (Coturnix coturnix japonica L.) after Cultivated with Monochromatic Light}

\author{
Norma Winata $^{1 *}$, Koen Praseno ${ }^{2}$, Silvana Tana $^{2}$ \\ ${ }^{1}$ Program Studi Biologi, Departemen Biologi, Fakultas Sains dan Matematika, Universitas Diponegoro \\ ${ }^{2}$ Departemen Biologi, Fakultas Sains dan Matematika, Universitas Diponegoro \\ Jl. Prof. Soedarto, SH, Tembalang, Semarang \\ *Email : winoto042@gmail.com
}

Diterima 20 September 2015 / Disetujui 28 Agustus 2017

\begin{abstract}
ABSTRAK
Puyuh (Coturnix coturnix japonica L.) merupakan salah satu jenis aves yang memiliki produktivitas tinggi dengan masa pemeliharaan yang relatif singkat. Puyuh memiliki dua fase pemeliharaan, yaitu fase pertumbuhan dan fase produksi. Pertumbuhan puyuh dipengaruhi oleh faktor internal dan eksternal. Cahaya merupakan salah satu faktor eksternal yang mempengaruhi pertumbuhan aves. Proses pertumbuhan seperti pertambahan bobot dan ukuran tubuh serta pola tingkah laku makan dipengaruhi oleh sistem hormonal yang diregulasi oleh cahaya. Penelitian ini bertujuan melihat potensi cahaya monokromatik terhadap pertumbuhan puyuh. Metode yang digunakan adalah pencahayaan monokromatik sebagai perlakuan dalam 3 warna, yaitu merah, hijau, dan biru, serta kontrol sebagai pembanding menggunakan lampu pijar. Perlakuan dimulai pada saat puyuh berusia 4 minggu sampai 12 minggu. Penelitian ini menggunakan Rancangan Acak Lengkap (RAL). Data yang dihasilkan dalam penelitian ini dianalisis menggunakan Analysis of Varian (ANOVA), karena terdapat perbedaan nyata maka dilanjutkan dengan Uji Duncan pada taraf kepercayaan 95\%. Parameter dalam penelitian ini adalah bobot tubuh, pertambahan bobot tubuh, konsumsi pakan, dan konversi pakan. Hasil penelitian ini menunjukkan adanya perbedaan nyata pada bobot tubuh puyuh dan pertambahan bobot tubuh dari perlakuan cahaya monokromatik terhadap kontrol. Simpulan dari penelitian ini adalah pencahayaan dengan cahaya monokromatik warna hijau lebih berpotensi meningkatkan pertumbuhan puyuh.
\end{abstract}

Kata kunci : puyuh (Coturnix coturnix japonica L.), pertumbuhan, cahaya monokromatik

\begin{abstract}
Quail ( Coturnix coturnix japonica L. ) was a species of bird that had a high productivity with relatively short maintenance period. The quail has two maintenance phases, namely the growth phase and the production phase. Quail growth was influenced by internal and external factors. Light was one of the external factors influencing the growth of aves. The process of growth such as weight gain and body size and eating behavior patterns were influenced by hormonal system that was regulated by light. The objective of this research was examined the potential of monochromatic light on the growth of quail . The method used monochromatic lighting as a treatment in three colours, there were red, green, and blue, as well as a comparison control using incandescent lamps. Treatment was initiated when the quail aged 4 weeks to 12 weeks . The research design was based on completely randomized design ( CRD ). The result of the data in this research were analyzed by using Analysis of variants ( ANOVA ), because there was a real difference then continued by Duncan test at the $95 \%$ significance level. The parameters of the research were body weight, body weight gain, feed intake, and feed conversion. The results of this research showed a significant difference in body weight of quail and body weight gain of monochromatic light treatments to control. Conclusions from this research was monochromatic lighting with green color were more likely to increase growth quail .
\end{abstract}

Keywords: quail (Coturnix coturnix japonica L.), growth, monochromatic light 


\section{PENDAHULUAN}

Puyuh (Coturnix coturnix japonica L.) merupakan salah satu komoditi unggas yang mempunyai peran dan prospek yang baik sebagai penghasil telur dan daging. Daging puyuh digemari karena mengandung protein yang tinggi (21.1\%) dan rendah lemak (7.7\%). Daging puyuh umumnya diperoleh dari puyuh yang sudah afkir. Puyuh dikatakan afkir bila kemampuan bertelurnya telah menurun dan puyuh jantan yang tidak terpilih sebagai pejantan. Saat ini hanya beberapa supermarket yang menyediakan daging puyuh yang dijual dalam bentuk karkas (Tetty, 2002).

Puyuh termasuk unggas yang mempunyai keunggulan sebagai hewan ternak. Keunggulan puyuh terutama (1) pada usia 41 hari puyuh betina sudah dapat menghasilkan telur, (2) dalam satu tahun bisa dihasilkan 250 sampai 300 butir telur dengan berat rata-rata $10 \mathrm{gram} / \mathrm{butir}$, (3) tidak memerlukan lahan/ruang yang luas,(4) lebih adaptif pada kondisi lingkungan (penyakit dan suhu), (5) telur dan puyuh memiliki nilai tukar yang tinggi dan mudah dipasarkan,(6) telur dan dagingpuyuh bergizi tinggi, (7) nilai unsur hara kotoran puyuh sebagai pupuk lebih baik dibandingkan kotoran ternak lainnya, (8) puyuh lebih toleran jika diberikan pakan dengan serat kasar tinggi di bandingkan dengan ayam ras. Berdasarkan berbagai keunggulan tersebut, budidaya puyuh dapat meningkatkan pendapatan dan kesejahteraan masyarakat (Sutoyo,1989).

Berbagai upaya dilaksanakan untuk meningkatkan produktivitas puyuh dalam skala budidaya, seperti penambahan hormon, manipulasi pakan, serta pemberian cahaya tambahan dengan tujuan akhir pertumbuhan puyuh menjadi optimal sehingga produktivitas menjadi lebih baik. Cahaya merupakan salah satu faktor eksternal yang dapat memacu pertumbuhan dan mengendalikan berbagai proses biologis dalam tubuh unggas. Sesuai dengan pernyataan Cao et al., (2008) dan Prayitno et al., (2006) cahaya mutlak diperlukan karena berfungsi sebagai penghangat, penerangan, dan yang paling penting, pada masa produksi, pencahayaan yang baik akan mampu meningkatkan produksi telur hingga $75 \%$. Usaha budidaya puyuh yang telah banyak dilakukan secara tradisional belum sepenuhnya menggunakan cahaya tambahan untuk meningkatkan produktivitas puyuh. Berbagai program pencahayaan yang terdiri atas warna cahaya, periode pencahayaan, dan intensitas cahaya dapat meningkatkan fungsi biologis yang secara langsung memacu pertumbuhan puyuh. Terkait dengan fungsi biologis tersebut, penelitian mengenai penggunaan cahaya monokromatik sebagai alternatif penerangan tambahan malam hari pada puyuh sangat penting untuk dilakukan dengan tujuan pertumbuhan dan perkembangan puyuh menjadi lebih baik lagi.

\section{METODE PENELITIAN}

\section{Tempat dan Waktu Penelitian}

Laboratorium Biologi Struktur dan Fungsi Hewan, Fakultas Sains dan Matematika, Universitas Diponegoro, Semarang. Penelitian dilakukan pada bulan Mei-Juli 2012.

\section{Hewan Uji}

Hewan uji yang digunakan pada penelitian ini adalah puyuh jepang (Coturnix coturnix japonica L.) dengan jumlah 60 ekor. Puyuh dibagi ke dalam 4 kelompok perlakuan percobaan yaitu:

P0: Kelompok puyuh dengan pencahayaan lampu pijar $5 \mathrm{~W}$ sebagai kontrol

P1: Kelompok Puyuh dengan pencahayaan dengan lampu LED $5 \mathrm{~W}$ warna merah

P2: Kelompok Puyuh dengan pencahayaan dengan lampu LED $5 \mathrm{~W}$ warna hijau

P3: Kelompok Puyuh dengan pencahayaan dengan lampu LED $5 \mathrm{~W}$ warna biru

Kandang yang dipakai dalam penelitian ada dua macam, yakni kandang kolektif yang digunakan pada saat aklimasi, memiliki ukuran 80x80x40 cm dan kandang baterai dengan ukuran $30 \times 40 \times 45 \mathrm{~cm}$. Kandang baterai dibuat dengan kombinasi kawat ram/kasa dan kayu. Telur yang dikeluarkan oleh puyuh akan menggelinding keluar dan terkumpul disatu tempat. Setiap satu unit kandang baterai terdiri atas 4 buah kotak kandang, dan masing-masing kotak diberi partisi 
sehingga terdiri atas 4 buah kotak kandang, dan masing-masing kotak diberi sekat partisi yang dilapisi alumunium foil sehingga setiap satu kotak hanya disinari oleh cahaya warna tertentu.

\section{Cara Kerja}

Kandang kolektif disiapkan, dibersihkan dari kotoran, disemprot desinfektan, diberi penerangan menggunakan lampu berwarna kuning 25 watt, kemudian alas diberi sekam yang disemprot desinfektan yang bertujuan untuk membunuh bakteri pengganggu yang ada.

Puyuh diaklimasi selama 2 minggu dalam kandang kolektif, kemudian ditimbang untuk menyeragamkan bobot badan. Puyuh dengan bobot 30,0-40,0 g dipilih sebagai hewan coba, selanjutnya ditempatkan dalam kandang baterai selama 1 minggu untuk menyesuaikan faktor fisik lingkungan dan manajemen pemeliharaan sebelum diberi perlakuan. Puyuh umur 3 minggu mulai diberi perlakuan cahaya monokromatik selama 12 jam per hari dari pukul 18.00-06.00 WIB. Pemberian cahaya diberikan selama 8 minggu.

Sanitasi kandang dan perlengkapannya dilakukan sebelum puyuh ditempatkan dalam kandang kolektif maupun kandang baterai. Tempat pakan, tempat minum, dan ruangan kandang dibersihkan secara rutin setiap pagi hari dan sanitasi kandang dilakukan setiap satu minggu dua kali, dengan menyemprotkan desinfektan.

Selama penelitian puyuh diberi makan dan minum secara ad libitum, feses dibersihkan dua hari sekali pada pagi hari. Temperatur dan kelembaban lingkungan diukur setiap pagi (pukul 07.00 WIB), siang (pukul 13.00 WIB), dan sore (pukul 17.00 WIB) hari menggunakan termohigrometer.

Pakan yang diberikan pada puyuh percobaan adalah pakan standar yang disesuaikan dengan umur pemeliharaan, yaitu pakan pada fase pertumbuhan dan pakan pada fase bertelur.

Pemberian vitamin antistress dilakukan setelah pindah kandang selama 3 hari berturutturut, serta sebelum dan sesudah vaksinasi. Selama penelitian juga diberi vaksin Newcastle Disease 1 (ND1) secara diteteskan pada mata pada umur 4 hari dan Newcastle Disease 2 (ND2) melalui air minum pada umur 20 hari.

\section{Pengambilan Data}

Parameter yang diukur dan diamati adalah bobot tubuh, pertambahan bobot tubuh, konsumsi pakan, dan konversi pakan.

\section{Bobot Tubuh}

Bobot tubuh diukur dengan menimbang puyuh pada akhir penelitian. Timbangan yang dipergunakan memiliki kapasitas beban maksimum $1000 \mathrm{~g}$.

\section{Pertambahan Bobot Tubuh}

Pertambahan bobot tubuh diperoleh dengan menghitung selisih antara bobot tubuh dari minggu akhir (minggu ke 9) dan minggu pertama (minggu ke 4) perlakuan.

\section{Konsumsi Pakan}

Konsumsi pakan diukur dengan menghitung selisih antara pakan yang diberikan dengan jumlah yang tersisa selama 1 minggu pemberian pakan sehingga dapat diperoleh konsumsi pakan harian dalam satuan g/ekor per hari. Timbangan Ohaus yang dipergunakan memiliki kepekaan $0,1 \mathrm{~g}$.

\section{Konversi Pakan}

Konversi pakan dihitung dari jumlah pakan yang dikonsumsi (g) dibagi pertambahan bobot tubuh $(\mathrm{g})$ atau ( $\left.\frac{\text { konsumsi pakan }}{\text { bobot tubuh }}\right)$

\section{Konsumsi Minum}

Konsumsi minum diukur dengan menghitung selisih antara minum yang diberikan dengan jumlah yang tersisa setiap hari dalam satuan $\mathrm{ml} /$ ekor per hari menggunakan gelas ukur.

\section{Rancangan Penelitian}

Rancangan penelitian yang digunakan adalah Rancangan Acak Lengkap, dengan 4 perlakuan dan 5 kali ulangan.

\section{Analisis Data}

Data yang diperoleh kemudian dianalisis dengan ANOVA dengan uji lanjut Uji Duncan pada taraf kepercayaan $95 \%$.

\section{HASIL DAN PEMBAHASAN}

Hasil analisis rata-rata bobot tubuh, pertambahan bobot tubuh, konsumsi pakan, dan konversi pakan pada puyuh (Coturnix coturnix japonica L.) setelah pemberian cahaya 
monokromatik dengan menggunakan uji ANOVA pada taraf kepercayaan 95\% yang dilanjutkan dengan uji Duncan disajikan pada Tabel 1. Hasil analisis rata-rata konsumsi pakan pada kontrol menunjukan adanya perbedaan nyata terhadap ke 3 perlakuan cahaya monokromatik. Kelompok perlakuan pencahayaan dengan lampu warna hijau (P2) menunjukkan rata-rata pakan yang dikonsumsi tidak lebih tinggi dari pada P1 dan P0 dan tidak lebih rendah dari $\mathrm{P}$, yaitu sebesar 17.65 g/ekor/hari. Puyuh dengan pencahayaan monokromatik warna hijau (P2) memiliki bobot tubuh paling tinggi dibandingkan dengan puyuh yang diberikan pencahayaan monokromatik dengan warna merah (P1), biru (P3) maupun lampu pijar (P0). Puyuh dengan pencahayaan monokromatik warna hijau (P2) dapat dikatakan mampu mengoptimalkan metabolisme pakan yang dikonsumsi lebih baik pada proses pertumbuhan dibandingkan dengan puyuh yang menerima pencahayaan warna merah (P1), biru (P3), dan lampu pijar (P0). Konversi pakan pada pencahayaan wara hijau (P2) yaitu 0.10 yang lebih kecil dari hasil konversi pakan pencahayaan lampu pijar (P0) dan warna merah (P1) menunjukkan pakan yang dikonsumsi puyuh lebih efisien digunakan oleh puyuh pada perlakuan cahaya warna hijau (P2). Gewerh et al., (2005) menyatakan pemberian cahaya hijau akan menstimulasi pertumbuhan pada periode anak dan masing-masing warna cahaya mampu menghasilkan efek tingkah laku, pertumbuhan, reproduksi yang berbeda dalam kehidupan hewan.

Tabel 1. Hasil analisis rata-rata bobot tubuh, pertambahan bobot tubuh, konsumsi minum dan konsumsi pakan pada puyuh (Coturnix coturnix japonica L.) setelah pemberian cahaya monokromatik

\begin{tabular}{lcccc}
\hline \multicolumn{1}{c}{ Variabel yang diamati } & P0 & P1 & P2 & P3 \\
\hline $\begin{array}{l}\text { Bobot tubuh (gr) } \\
\text { Pertambahan bobot tubuh }\end{array}$ & $158.00^{\mathrm{b}}$ & $166.00^{\mathrm{b}}$ & $176.00^{\mathrm{a}}$ & $166^{\mathrm{b}}$ \\
$\begin{array}{l}\text { (gr/ekor/hari) } \\
\text { Konsumsi minum }\end{array}$ & $16.00^{\mathrm{b}}$ & $26.00^{\mathrm{ab}}$ & $28.00^{\mathrm{a}}$ & $26.00^{\mathrm{ab}}$ \\
$\begin{array}{l}\text { (ml/ekor/hari) } \\
\text { Konsumsi pakan }\end{array}$ & $31.71^{\mathrm{a}}$ & $32.43^{\mathrm{a}}$ & $30.01^{\mathrm{a}}$ & $30.14^{\mathrm{a}}$ \\
$\begin{array}{l}\text { (gr/ekor/hari) } \\
\text { Konversi pakan }\end{array}$ & $20.33^{\mathrm{a}}$ & $18.04^{\mathrm{b}}$ & $17.65^{\mathrm{b}}$ & $16.33^{\mathrm{b}}$ \\
\hline
\end{tabular}

Keterangan : Angka yang diikuti dengan superskrip yang sama pada baris yang sama menunjukkan perbedaan tidak nyata , PO : puyuh dengan pencahayaan lampu pijar, P1 : puyuh dengan pencahayaan warna merah, P2 : puyuh dengan pencahayaan warna hijau, P3 : puyuh dengan pencahayaan warna biru

Aktivitas makan dipengaruhi oleh cahaya dan pada saat gelap hampir tidak ada aktivitas makan. Pemberian cahaya menyebabkan puyuh memiliki kesempatan makan lebih lama sehingga konsumsi pakan lebih tinggi. Cahaya yang diterima oleh retina pada kelenjar pineal diteruskan ke hipotalamus sebagai pusat kerja hormonal, terdapat sel-sel yang akan meneruskan ke hipofisis untuk mengaktifkan hormon-hormon yang merangsang pertumbuhan seperti Growth hormone (GH) dan Thyroid stimulating hormone (TSH). Growth hormone (GH) berfungsi dalam merangsang pertumbuhan dengan mempengaruhi metabolisme asam amino pada kenaikan massa otot. Thyroid stimulating hormone (TSH) bersama tiroksin berperan dalam mengontrol tingkat metabolisme tubuh, membantu mengatur pertumbuhan tulang dengan hormon pertumbuhan. Hormon tiroid diperlukan untuk perkembangan sel-sel dan metabolisme protein dan lemak dalam tubuh. Cahaya dapat merangsang nafsu makan karena dengan adanya cahaya yang berfungsi dalam proses penglihatan. Pemberian cahaya pada malam hari menyebabkan aktivitas makan puyuh meningkat atau menurun tergantung dari sifat cahaya tersebut (Yuwanta, 2004).

Penelitian Rozenboim et al., (2004) menyatakan bahwa puyuh dipelihara dengan 
cahaya hijau mengalami peningkatan signifikan pada bobot badan dibandingkan jika dipelihara dengan cahaya lampu merah atau putih. Lampu hijau menyebabkan unggas menjadi lebih tenang sehingga mendorong pertumbuhan usia dini dengan meningkatkan proliferasi sel satelit otot rangka. Perilaku puyuh menjadi lebih tenang, menyebabkan pakan yang dikonsumsi dapat dimanfaatkan sepenuhnya dalam proses pertumbuhan dan perkembangan usia dini dibantu oleh Growth Hormone (GH) dalam menaikkan massa otot.

Hasil analisa rata-rata konversi pakan menunjukkan adanya perbedaan nyata, antara kontrol dan ke 3 perlakuan pencahayaan. Penggunaan pakan secara optimal terjadi pada kelompok puyuh dengan pencahayaan warna hijau (P2) yaitu 0.10 yang mampu menghasilkan bobot tubuh tertinggi (176.00 g/ekor) dengan aktivitas konsumsi pakan yang cukup rendah (17.65 g/ekor/hari). Efisiensi penggunaan pakan terbaik adalah pada kelompok puyuh dengan pencahayaan warna hijau dan efisiensi penggunaan pakan terburuk adalah pada kelompok puyuh dengan pencahayaan lampu pijar. Hal ini sesuai dengan Ensminger (1992), konversi pakan merupakan perbandingan antara jumlah pakan yang dikonsumsi (gram) dengan produksi telur atau bobot tubuh (gram) yang dihasilkan. Semakin rendah angka konversi pakan berarti efisiensi penggunaan pakan semakin tinggi dan sebaliknya semakin tinggi angka konversi pakan berarti tingkat efisiensi pakan semakin rendah. Hal ini ditunjukkan pada pencahayaan lampu pijar dengan konversi pakan tertinggi yaitu sebesar 0.13. Konversi pakan pada pencahayaan warna biru tidak seefisien pada pencahayaan warna hijau yaitu sebesar 0.10 karena tidak menghasilkan bobot tubuh yang tidak lebih tinggi dari pada bobot tubuh pada cahaya hijau. Siregar (1994), menyatakan adanya perbedaan hasil konversi pakan disebabkan oleh ketersediaan zat-zat gizi dalam pakan dan kesehatan ternak, semakin tinggi nilai konversi pakan berarti pakan yang digunakan untuk menaikkan bobot tubuh persatuan berat semakin banyak atau efisiensi pakan rendah, selain itu kondisi ternak, daya cerna, jenis kelamin, bangsa, kualitas dan kuantitas pakan, serta faktor lingkungan mempengaruhi besarnya konversi pakan tersebut (Haryanti, 2009).

Data pertambahan bobot tubuh puyuh diambil dari awal perlakuan yaitu umur 4 minggu hingga sebelum bertelur yaitu umur 9 minggu. Hal ini dilakukan untuk menghindari adanya stress bila dilakukan pengambilan data setelah bertelur karena akan mengakibatkan menurunnya produktivitas. Data analisis rata-rata pertambahan bobot tubuh menunjukkan adanya perbedaan yang nyata pada perlakuan pencahayaan warna hijau (P2) terhadap kontrol sedangkan pada perlakuan pencahayaan merah (P1) dan biru (P3) tidak menunjukkan perbedaan nyata. Data yang diperoleh menunjukkan bahwa kelompok puyuh dengan penerangan cahaya hijau (P2) memiliki pertambahan bobot tubuh paling tinggi yaitu 28.00 (g/ekor/hari) sedangkan kelompok puyuh dengan penerangan cahaya lampu pijar (P0) adalah paling rendah yaitu sekitar 16.00 (g/ekor/hari). Pertambahan bobot tubuh yang signifikan diperoleh dari tingkah laku keseharian puyuh dan efek cahaya hijau yang diberikan. Cahaya hijau menstimulus puyuh menjadi lebih tenang sehingga metabolisme yang terjadi lebih efisien seperti metabolisme pakan dan protein yang menghasilkan pertambahan bobot lebih signifikan.

Peningkatan bobot tubuh ini berkaitan dengan peningkatan bobot muskulus pektoralis, bobot tulang pektoralis, panjang tulang femur, dan tibia. Cahaya biru dengan panjang gelombang pendek $(450 \mathrm{~nm})$ diasumsikan memberikan efek yang menenangkan bagi puyuh. Kondisi yang tenang dengan respons stres minimal memacu proses degradasi substrat menjadi energi yang dipergunakan untuk segala aktivitas puyuh, terutama dimanfaatkan untuk mengoptimalkan pertumbuhan hingga fase puncak pertumbuhan (Kasiyati dkk., 2011).

Kelompok puyuh dengan penerangan cahaya merah (P1) menunjukkan rata-rata konsumsi minum tertinggi bila dibandingkan dengan kelompok puyuh dengan penerangan lainnya yaitu sebesar 32,43 (ml/ekor/hari). Aktivitas harian puyuh yang diberi cahaya monokromatik merah cukup tinggi dipicu oleh neurotransmiter tertentu 
sehingga puyuh mudah terstimulasi dan menjadi lebih agresif. Aktivitas yang tinggi ini memerlukan energi yang cukup sehingga diperlukan asupan nutrien dan air yang tinggi.

Rata-rata temperatur dan kelembaban pada saat penelitian adalah $27,68^{\circ} \mathrm{C}-31^{\circ} \mathrm{C}$ dengan kelembaban 40,89-60,62\%. Temperatur lingkungan selama pemeliharaan puyuh pada penelitian ini tidak sesuai dengan temperature ideal, sedangkan kelembaban lingkungan sudah sesuai yang dikemukakan oleh Tetty (2002) yang menyatakan bahwa suhu lingkungan yang optimal untuk puyuh adalah $20^{\circ} \mathrm{C}-25^{\circ} \mathrm{C}$. Kelembaban lingkungan untuk pertumbuhan dan perkembangan puyuh secara optimal antara 30-80\%. Suhu dan kelembaban udara sekitar juga mempengaruhi konsumsi minum itu sendiri, suhu yang tinggi menyebabkan puyuh mengkonsumsi air lebih banyak untuk homeostasis tubuh agar terhindar dari dehidrasi. Sebaliknya, suhu rendah akan menghemat air yang dikonsumsi.

Pakan dan lingkungan sangat mendukung terjadinya pertambahan bobot tubuh puyuh. Pakan dengan kualitas baik memacu pertumbuhan yang optimal yang merangsang sintesis protein dan karbohidrat yang akan di deposisikan dalam bentuk pertambahan massa tulang dan bulu serta lemak tubuh. Temperatur tinggi menekan konsumsi pakan puyuh karena metabolisme tubuh yang terjadi juga tinggi untuk mendapatkan keseimbangan suhu tubuh dengan lingkungan luar, sebaliknya temperatur rendah memacu banyaknya konsumsi pakan puyuh untuk menghasilkan energi dan homeostasis tubuh.

\section{KESIMPULAN}

Berdasarkan hasil di atas, maka simpulan yang dapat diambil adalah pencahayaan monokromatik warna hijau berpotensi lebih meningkatkan pertumbuhan puyuh.

\section{DAFTAR PUSTAKA}

Cao, J., Liu, Z., Wang, D., Xie, D., Jia, L., and Chen, Y. 2008. Green and blue monochromatic light promote growth and development of broilers via stimulating testosterone secretion and myofiber growth.
Journal Appl Poult Res Tetty. 2002. Puyuh, Si Mungil Penuh Potensi. Jakarta. Agro Media Pustaka.

Ensminger, M. A. 1992. Poultry Science (Animal Agricultural Series). 3th Edition. Instate Publisher, Inc. Danville, Illiones.

Gewehr, C.E., Cotta, J.T., Oliviera, A.I.G., and de Freitas, H.J. 2005. Effect of lighting programs on the egg production of quails (Coturnix coturnix japonica).

Haryanti, N.W. 2009. Kualitas Pakan Dan Kecukupan Nutrisi Sapi Simental Di Peternakan Mitra Tani Andini, Kelurahan Gunung Pati, Kota Semarang. Laporan praktek Kerja Lapangan. Fakultas Peternakan. Universitas Diponegoro

Kasiyati, Silalahi, A.B., dan Permatasari, I. 2011. Optimasi Pertumbuhan Puyuh (Coturnix coturnix japonica L.) Hasil Pemeliharaan dengan Cahaya Monokromatik. Anatomi Fisiologi, XIX (2). pp. 55-64. ISSN 08545367

Prayitno, D.S., Phillips, C.J., and Omed, H. 2006. The effect color of lightting on behaviour and production of meatchickens. Journal Appl Poult Res

Rozenboim, I., Biran I., Chaiseha, Y., Yahav, S., Rosenstauch, A., Sklan, D., and Halevy, O. 2004. The effect of green and blue light monochromatic light combination broiler growth and development. Poultry Science 83 (5): 842-845.

Siregar, S. B. 1994. Ransum Ternak Ruminansia. Penebar Swadaya. Jakarta.

Sutoyo. 1989. Petunjuk Praktis Beternak Puyuh. Titi Terang. Jakarta.

Tetty. 2002. Puyuh, Si Mungil Penuh Potensi. Jakarta. Agro Media Pustaka.

Yuwanta, T. 2004. Dasar Ternak Unggas. Kanisius. Yogyakarta 